\title{
EFEKTIVITAS PERAN DINAS PEMBERDAYAAN PEREMPUAN DAN PERLINDUNGAN ANAK DALAM MENCEGAH TINDAK KEKERASAN PADA PEREMPUAN DAN ANAK DI KOTA MATARAM PROVINSI NUSA TENGGARA BARAT
}

\author{
Lalu ulung ilham ${ }^{1}$ Novia Suhastini ${ }^{2}$ \\ Jurusan Ilmu Pemerintahan Universitas Muhammadiyah Mataram
}

Email: noviasuhastini@ymail.com

\begin{abstract}
ABSTRAK
Kota Mataram adalah salah satu kota yang ada di Provinsi Nusa Tenggara Barat yang aktif melaksanakan program perlindungan dan pemberdayaan anak. Namun, Berdasarkan hasil observasi ada beberapa permasalahan terkait perlindungan anak yang ada di Kota Mataram yaitu masih adanya berbagai bentuk kekerasan. Mengingat anak adalah generasi penerus bangsa di masa depan, maka sudah selayaknya sebagai negara yang bijak senantiasa berusaha menjaga generasi mudanya dari segala kemungkinan terburuk yang mungkin terjadi. Untuk melihat efektifitas dinas pemberdayaan perempuan dan perlindungan anak dalam pencehagan tindak kekerasan akan dianalisis menggunakan metode penelitian kualitatif dengan pendekatan deskriptif, sumber data yang digunakan dalam penelitian ini adalah data primer dan data skunder. Data primer adalah data yang diperoleh dari hasil wawancara dengan berbagai informen yang dilakukan peneliti. Data skunder adalah data-data berupa dokumen, buku, arsip dan lain-lain yang erat kaitannya dengan penelitian.

Berdasarkan hasil penelitian yang telah dilakukan peneliti dapat simpulkan bahwa jumlah kekerasan terhadap perempuan dan anak sampai dengan Juli 2017 mencapai 68 kasus. Dengan rincian kekerasan terhadap perempuan sebanyak 63 persen dan anak sebesar 25 persen. Kekerasan ini didominasi oleh kekerasan fisik, seksual dan juga Kekerasan Dalam Rumah Tangga (KDRT). Ada berbagai penyebab, salah satunya faktor ekonomi suatu keluarga yang terkategori tidak stabil. Masih adanya beberapa permasalahan yang terjadi menyebabkan Peran Dinas Pemberdayaan Perempuan dan Perlindungan Anak dalam mencegah tindak kekerasan pada perempuan dan anak di Kota Mataram belum terlaksana secara efektif.
\end{abstract}

\section{Kata Kunci : Efektivitas, peran, Pemberdayaan perempuan dan anak.}

\section{LATAR BELAKANG}

Menurut Undang-Undang No. 35 Tahun 2014, anak didefinisikan sebagai seseorang yang belum berusia 18 (delapan belas) tahun, termasuk anak yang masih dalam kandungan. Dari definisi tersebut telah jelas bahwa anak merupakan seseorang yang jika dilihat dari usianya maka anak sangat memerlukan bimbingan dan perlindungan dari orang tua terutama dalam proses pemenuhan kebutuhannya.

Salah satu hal mendasar yang telah dilakukan oleh negara dalam rangka perlindungan terhadap anak adalah dengan mengeluarkan suatu undangundang yaitu Undang-Undang No. 35 Tahun 2014 tentang Perlindungan Anak. Undang-Undang ini mengatur tentang hak dan kewajiban anak serta semua hal terkait perlindungan anak. Dengan adanya Undang-Undang ini diharapkan anak-anak Indonesia dapat terlindungi seutuhnya. Mengingat anak adalah generasi penerus bangsa di masa depan, maka sudah selayaknya sebagai negara yang bijak senantiasa berusaha menjaga generasi mudanya dari segala kemungkinan terburuk yang mungkin terjadi.

Kota Mataram adalah salah satu kota yang ada di Provinsi Nusa Tenggara Barat yang juga aktif melaksanakan program perlindungan dan pemberdayaan anak. Sesuai dengan instruksi Undang-Undang No. 35 Tahun 2014 tentang Perlindungan Anak maka pemerintah Kota Mataram harus melindungi dan melihat potensi yang ada pada anak-anak yang ada.

Berdasarkan hasil observasi, ada beberapa permasalahan terkait perlindungan anak yang ada di Kota Mataram yaitu masih adanya berbagai bentuk kekerasan dan bagaimana menghindari diri dari kekerasan, tetapi sangat dirasa perlu juga untuk belajar bagaimana memanfaatkan potensi diri yang didalamnya terdapat muatan-muatan positif dimana setiap pribadi baik orang dewasa maupun anak-anak dapat tumbuh dan mengembangkan potensi dirinya secara optimal jauh dari ketakutan akan kekerasankekerasan baru, dan diyakini dengan cara ini lingkaran setan kekerasan dapat terputus.

Kasus kekerasan terhadap perempuan dan anak di kota Mataram masih tinggi. Dinas Pemberdayaan Perempuan dan Perlindungan Anak (DP2PA) Kota Mataram mencatat, jumlah kekerasan terhadap perempuan dan anak sampai dengan Juli 2017 mencapai 68 kasus. Dengan rincian kekerasan terhadap perempuan sebanyak 63 persen dan anak sebesar 25 persen. Kekerasan ini didominasi oleh kekerasan fisik, seksual dan juga Kekerasan Dalam 
Rumah Tangga (KDRT). Ada berbagai penyebab, salah satunya faktor ekonomi suatu keluarga yang terkategori tidak stabil.

Mengingat anak adalah generasi penerus bangsa di masa depan, maka sudah selayaknya sebagai negara yang bijak senantiasa berusaha menjaga generasi mudanya dari segala kemungkinan terburuk yang mungkin terjadi. Pembinaan terhadap generasi muda harus selalu dilakukan agar kelangsungan hidup, pertumbuhan dan perkembangan fisik dan mental serta perkembangan sosialnya tetap terjaga dengan baik.

\section{KERANGKA TEORI}

\section{A. Good Governance}

Kooiman (dalam Sedarmayanti, 2009:273:) bahwa Governance adalah serangkaian proses interaksi sosial politik antara pemerintahan dengan masyarakat dalam berbagai bidang yang berkaitan dengan kepentingan masyarakat dan intervensi pemerintah atas kepentingan-kepentingan tersebut.

Istilah "governance" tidak hanya berarti kepemerintahan sebagai suatu kegiatan, tetapi juga mengandung arti pengurusan, pengelolaan, pengarahan, pembinaan penyelenggaraan dan bisa juga diartikan pemerintahan. Oleh karena itu tidak mengherankan apabila terdapat istilah good governance yaitu kepmerintahan yang baik.

Governance merupakan terminologi yang digunakan menggantikan istilah goverment, menunjukan penggunaan otoritas politik dalam mengelola masalah kenegaraan. Istilah ini secara khusus menggambarkan peranan pemerintah dari pemberi pelayanan kepada fasilitator, dan perubahan kepemilikan dari milik negara menjadi milik rakyat. Pusat perhatian utama governance adalah perbaikan kinerja atau perbaikan kualitas. Governance berarti proses pengambilan keputusan dan proses di mana keputusan di implementasikan atau tidak di implementasikan.

Governance lebih merupakan serangkaian proses interaksi sosial politik antara pemerintah dengan masyarakat dalam berbagai bidang yang berkaitan dengan kepentingan masyarakat dan intervensi pemerintah.

MM. Billah (dalam Azra 2003: 180), istilah good governance merujuk pada arti asli kata governing yang berarti mengarahkan atau mengendalikan atau mempengaruhi masalah publik dalam suatu negeri. Karena itu good governance dapat diartikan sebagai tindakan atau tingkah laku yang didasarkan pada nilai-nilai yang bersifat mengarahkan, mengendalikan, atau mempengaruhi masalah publik untuk mewujudkan nilai-nilai itu dalam tindakan dan kehidupan keseharian. Dengan demikian ranah good governance tidak terbatas pada negara atau birokrasi pemerintahan, tetapi juga pada ranah masyarakat sipil yang direpresentasikan oleh organisasi non-pemerintah seperti Lembaga Swadaya Masyarakat (LSM) dan juga sektor swasta.

Sedangkan, Taylor (dalam Azra 2003: 181) menegaskan bahwa good governance adalah pemerintahan demokratis seperti yang dipraktikkan dalam negara-negara demokrasi maju di Eropa Barat dan Amerika misalnya. Konsep good governance memberikan rekomendasi pada sistem pemerintahan yang menekankan kesetaraan antara lembaga-lembaga negara baik di tingkat pusat maupun daerah, sektor swasta, dan masyarakat sipil (civil society).

Dari berbagai hasil kajiannya, Lembaga Administrasi Negara (LAN) telah menyimpulkan sembilan aspek fundamental dalam perwujudan good governance, yaitu:

1. Partisipasi (Participation)

2. Penegakan Hukum (Rule of Law)

3. Transparansi (Transparency)

4. Responsif (Responsiveness)

5.Orientasi Kesepakatan

Orientation)

6. Keadilan (Equity)

7. Efektivitas (Effectiveness) dan Efisiensi (Efficiency)

8. Akuntabilitas (Accountability)

9. Visi Strategis (Strategic Vision)

Dari penjelasan yang telah dijabarkan diatas dapat disimpulkan bahwa good governance adalah suatu pemerintahan yang baik yang menekankan kesetaraan antara lembaga-lembaga negara baik di tingkat pusat maupun daerah, sektor swasta, dan masyarakat sipil (civil society) dengan menggunakan sembilan prinsip yang telah disebutkan.

Dinas Pemberdayaan Perempuan dan Perlindungan Anak Kota Mataram adalah salah satu atau bagian dari "good governance" (Kepemerintahan yang baik) untuk mewujudkan tujuan dari perannya yaitu melindungi hak-hak perempuan dan anak yang ada di Kota Mataram. Untuk mewujudkan tujuan tersebut tentu harus melaksanakan perannya secara efektif agar di ketahuai sejauh mana ketercapaian tujuan atau seberapa besar tujuannya sudah tercapai.

\section{B. Perlindungan Anak}

Undang - Undang No. 35 Tahun 2014 tentang Perlindungan Anak Bab I Ketentuan umum pasal 1 nomor 1 menyebutkan pengertian anak adalah seseorang yang belum berusia 18 (delapan belas) tahun, termasuk anak yang masih dalam kandungan. Selanjutnya, Atmasasmita (1997: 83) mendefinisikan perlindungan anak adalah suatu usaha mengadakan 
kondisi dan situasi yang memungkinkan pelaksanaan hak dan kewajiban anak secara manusiawi positif. Selain itu,Triyanto (2013: 160) mendefinisikan perlindungan anak adalah segala kegiatan untuk menjamin dan melindungi anak dan hak-haknya agar dapat hidup, tumbuh, berkembang, dan berpartisipasi, secara optimal sesuai dengan harkat dan martabat kemanusiaan, serta mendapat perlindungan dari kekerasan dan diskriminasi.

Upaya perlindungan anak perlu dilaksanakan sedini mungkin, yakni sejak dari janin dalam kandungan sampai anak berumur 18 tahun. Hal ini bertujuan demi terwujudnya anak Indonesia yang berkualitas, berakhlak mulia dan sejahtera. Jadi dapat disimpulkan bahwa konsepsi perlindungan anak mencakup ruang lingkup yang luas, dalam arti bahwa perlindungan anak tidak hanya mengenai perlindungan atas jiwa dan raga anak, tapi mencakup pula perlidungan atas semua hak serta kepentingannya yang dapat menjamin pertumbuhan dan perkembangan yang wajar, baik secara rohaniah, jasmani maupun sosialnya sehingga diharapkan anak Indonesia akan berkembang menjadi orang Indonesia yang mampu dan mau berkarya untuk mencapai dan memelihara tujuan pembangunan nasional.

\section{Pengertian Efektifitas}

Kata efektif berasal dari bahasa Inggris yaitu effective yang berarti berhasil atau sesuatu yang dilakukan berhasil dengan baik. Kamus ilmiah populer mendefinisikan efetivitas sebagai ketepatan penggunaan, hasil guna atau menunjang tujuan. Efektivitas merupakan unsur pokok untuk mencapai tujuan atau sasaran yang telah ditentukan di dalam setiap organisasi, kegiatan ataupun program. Disebut efektif apabila tercapai tujuan ataupun sasaran seperti yang telah ditentukan. Hal ini sesuai dengan pendapat H. Emerson yang dikutip Soewarno Handayaningrat S. (1994:16) yang menyatakan bahwa "Efektivitas adalah pengukuran dalam arti tercapainya tujuan yang telah ditentukan sebelumnya." Sedangkan Georgopolous dan Tannembaum (1985:50), mengemukakan: "Efektivitas ditinjau dari sudut pencapaian tujuan, dimana keberhasilan suatu organisasi harus mempertimbangkan bukan saja sasaran organisasi tetapi juga mekanisme mempertahankan diri dalam mengejar sasaran.

Dengan kata lain, penilaian efektivitas harus berkaitan dengan mesalah sasaran maupun tujuan. Selanjutnya Steers (1985:87) mengemukakan bahwa: "Efektivitas adalah jangkauan usaha suatu program sebagai suatu sistem dengan sumber daya dan sarana tertentu untuk memenuhi tujuan dan sasarannya tanpa melumpuhkan cara dan sumber daya itu serta tanpa memberi tekanan yang tidak wajar terhadap pelaksanaannya”. Lebih lanjut menurut Agung
Kurniawan dalam bukunya Transformasi Pelayanan Publik mendefinisikan efektivitas, sebagai berikut: "Efektivitas adalah kemampuan melaksanakan tugas, fungsi (operasi kegiatan program atau misi) daripada suatu organisasi atau sejenisnya yang tidak adanya tekanan atau ketegangan diantara pelaksanaannya" (Kurniawan, 2005:109). Dari beberapa pendapat di atas mengenai efektivitas, dapat disimpulkan bahwa efektivitas adalah suatu ukuran yang menyatakan seberapa jauh target (kuantitas,kualitas dan waktu) yang telah dicapai oleh manajemen, yang mana target tersebut sudah ditentukan terlebih dahulu. Hal ini sesuai dengan pendapat yang dikemukakan oleh Hidayat (1986) yang menjelaskan bahwa :"Efektivitas adalah suatu ukuran yang menyatakan seberapa jauh target (kuantitas,kualitas dan waktu) telah tercapai. Dimana makin besar persentase target yang dicapai, makin tinggi efektivitasnya".

Mengukur efektivitas organisasi bukanlah suatu hal yang sangat sederhana, karena efektivitas dapat dikaji dari berbagai sudut pandang dan tergantung pada siapa yang menilai serta menginterpretasikannya. Bila dipandang dari sudut produktivitas, maka seorang manajer produksi memberikan pemahaman bahwa efektivitas berarti kualitas dan kuantitas (output) barang dan jasa.

Tingkat efektivitas juga dapat diukur dengan membandingkan antara rencana yang telah ditentukan dengan hasil nyata yang telah diwujudkan. Namun, jika usaha atau hasil pekerjaan dan tindakan yang dilakukan tidak tepat sehingga menyebabkan tujuan tidak tercapai atau sasaran yang diharapkan, maka hal itu dikatakan tidak efektif. Adapun kriteria atau ukuran mengenai pencapaian tujuan efektif atau tidak, sebagaimana dikemukakan oleh S.P. Siagian (1978:77), yaitu:

a. Kejelasan tujuan yang hendak dicapai, hal ini dimaksdukan supaya

karyawan dalam pelaksanaan tugas mencapai sasaran yang terarah dan tujuan organisasi dapat tercapai.

b. Kejelasan strategi pencapaian tujuan, telah diketahui bahwa strategi adalah "pada jalan" yang diikuti dalam melakukan berbagai upaya dalam mencapai sasaran-sasaran yang ditentukan agar para implementer tidak tersesat dalam pencapaian tujuan organisasi.

c. Proses analisis dan perumusan kebijakan yang mantap, berkaitan dengan tujuan yang hendak dicapai dan strategi yang telah ditetapkan artinya kebijakan harus mampu menjembatani tujuan-tujuan dengan usahausaha pelaksanaan kegiatan operasional. 
d. Perencanaan yang matang, pada hakekatnya berarti memutuskan sekarang apa yang dikerjakan oleh organisasi dimasa depan.

e. Penyusunan program yang tepat suatu rencana yang baik masih perlu dijabarkan dalam program-program pelaksanaan yang tepat sebab apabila tidak, para pelaksana akan kurang memiliki pedoman bertindak dan bekerja.

f. Tersedianya sarana dan prasarana kerja, salah satu indikator efektivitas organisasi adalah kemamapuan bekerja secara produktif. Dengan sarana dan prasarana yang tersedia dan mungkin disediakan oleh organisasi.

g. Pelaksanaan yang efektif dan efisien, bagaimanapun baiknya suatu program apabila tidak dilaksanakan secara efektif dan efisien maka organisasi tersebut tidak akan mencapai sasarannya, karena dengan pelaksanaan organisasi semakin didekatkan pada tujuannya.

h. Sistem pengawasan dan pengendalian yang bersifat mendidik mengingat sifat manusia yang tidak sempurna maka efektivitas organisasi menuntut terdapatnya sistem pengawasan dan pengendalian.

\section{Teori Peran}

Teori peran dikemukakan oleh Kahn dkk. (1964). Teori Peran menekankan sifat individual sebagai pelaku sosial yang mempelajari perilaku sesuai dengan posisi yang ditempatinya di lingkungan kerja dan masyarakat. Teori Peran mencoba untuk menjelaskan interaksi antar individu dalam organisasi, berfokus pada peran yang mereka mainkan. Setiap peran sosial adalah seperangkat hak, kewajiban, harapan, norma dan perilaku seseorang untuk menghadapi dan memenuhi perannya. Model ini didasarkan pada pengamatan bahwa orang berperilaku dengan cara yang dapat diprediksi, dan bahwa perilaku individu adalah konteks tertentu, berdasarkan posisi sosial dan faktor lainnya. Mereka menyatakan bahwa sebuah lingkungan organisasi dapat mempengaruhi harapan setiap individu mengenai perilaku peran mereka. Kantz dan Kahn (1978) menyatakan bahwa individu akan mengalami konflik dalam dirinya apabila terdapat dua tekanan atau lebih yang terjadi secara bersamaan yang ditujukan pada diri seseorang.

Peran yang tidak jelas, terjadi jika individu yang diberi peran yang tidak jelas dalam hal perilaku dan penampilan yang diharapkan. Role ambiguity merupakan kondisi stress yang di sebabkan oleh kebingungan karena ekspektasi peran tidak dipahami secara jelas dan tidak adanya informasi yang memadai yang di perlukan seseorang untuk memenuhi peran mereka secara memuaskan (Wiryathi, 2014).

Peran berlebih, terjadi jika individu menerima banyak peran (Keliat,1992). Mondy, et al. (1990:490) menyatakan bahwa role overload merupakan tipe konflik peran yang lebih kompleks, terjadi ketika harapan yang dikirimkan pada pemegang peran dapat digabungkan akan tetapi kinerja mereka melampaui jumlah waktu yang tersedia bagi orang yang melaksanakan aktivitas yang diharapkan.

Kahn (1964) menyatakan bahwa sebuah lingkungan organisasi dapat mempengaruhi harapan setiap individu mengenai perilaku peran mereka. Jika sering terjadi perubahan terhadap lingkungan organisasi akan memunculkan rasa yang tidak aman. Pada akhirnya, jika hal ini dibiarkan berlangsung lama, karyawan dapat menjadi stress akibat adanya rasa tidak aman dan pasti akan pekerjaannnya (Greenhalgh dan Rosenblatt, 1984).

\section{E. Pemberdayaan Perempuan Di Indonesia}

Di Indonesia, strategi pemberdayaan perempuan dilakukan secara bertahap. Hal ini tampak dari Program Keluarga Berencana (KB) dengan memberikan kesempatan yang lebih besar kepada kaum ibu dan keluarga pada umumnya untuk mengurangi beban yang dipikulnya dalam lingkungan keluarga dengan mengatur kehamilan dan kelahiran anak-anaknya. Dengan cara itu, perempuan dapat ikut berpartisipasi dalam pembangunan. Lebih dari itu, kaum ibu dapat ikut serta membangun keluarga, lingkungan serta mengembangkan sifat dan jiwa kewirausahaan dengan ikut serta dalam gerakan pemberdayaan ekonomi keluarga. Strategi pemberdayaan perempuan dalam paradigma keluarga berencana sebetulnya berpijak pada filosofi pembangunan yang menjadikan kaum perempuan sebagai mitra sejajar kaum laki-laki. Dari pemahaman inilah muncul sebuah keyakinpan bahwa pengingkaran citra kemanusiaan perempuan dalam interrelasinya dengan kaum laki-laki terutama dalam mengaktualisasikan jati diri, baik dalam ranah negara maupun ranah masyarakat bahkan keluarga merupakan fakta yang tidak layak memperoleh tempat di Indonesia yang demokratis. Lagi pula, jika upaya memberdayakan atau meningkatkan kualitas hidup perempuan benar-bnar dapat terwujud, tentu saja dapat mengatasi persoalan-persoalan yang menjerumuskan kaum perempuan itu ke dalam jurang kenestapaan.

\section{Metode Penelitian}


Penelitian ini tergolong pada tipe penelitian deskriptif dengan pendekatan kualitatif. Moleong (2011:6) penelitian kualitatif bermaksud untuk memahami fenomena tentang apa yang dialami oleh subyek penelitian misalnya, perilaku, persepsi, motivasi, tindakan, dll secara holistik, dan dengan cara deskriptif dalam bentuk kata-kata dan bahasa pada suatu konteks khusus yang alamiah dan dengan memanfaatkan berbagai metode ilmiah. Sumber data penelitian adalah data primer dan skunder. Data Primer yaitu berupa kata-kata dan tindakan (informan) serta peristiwa-peristiwa tertentu yang berkaitan dengan permasalahan penelitian, dan merupakan hasil pengumpulan peneliti sendiri selama berada di lokasi penelitian. Data Sekunder adalah data yang diperoleh atau dikumpulkan oleh orang yang melakukan penelitian dari sumber-sumber yang telah ada. Tehnik pengumpulan data menggunakan wawancara, observasi dan dokumentasi serta analisis dokumen dalam penelitian.

\section{HASIL DAN PEMBAHASAN}

\section{A. Efektivitas Dinas Pemberdayaan Perempuan dan Perlindungan anak di Kota Mataram}

Visi dan misi yang menjadi tujuan utama yang ingin di capai oleh Dinas Pemberdayaan Perempuan dan Perlindungan anak di Kota Mataram tentunya menjadi tantangan untuk di capai sesuai dengan tugas pokok dan fungsi yang telah ditetapkan dalam peraturan wali kota mataram Nomor 39 Tahun 2016 tentang kedudukan, susunan organisasi, tugas dan fungsi serta serta tata kerja Dinas Pemberdayaan Perempuan dan Perlindungan Anak Kota Mataram maka harus melaksanakan perumusan kebijakan teknis, pelaksanaan dan pengawasan agar hak perempuan dan anak di Kota Mataram terpenuhi.

Berdasarkan hasil wawancara dengan Kepala Dinas Pemberdayaan Perempuan dan Perlindungan anak Kota Mataram menyampaikan bahwa:

"Pelaksanaan peran yang kami lakukan tentunya sesuai dengan standar operasional prosedur (SOP) dan peraturan undangundang, kami melakukan beberapa kegiatan sosialisasi seperti pencegahan kekerasan terhadap anak dan perempuan, pemenuhan hak anak, dan pencegahan pernikahan usia dini, ini kami lakukan agar kedepanya tidak ada lagi kekerasan terhadap perempuan dan anak dan juga kesetaraan antara perempuan dan laki-laki" sumber: (hasil wawancara, 20 januari 2018).
Dari hasil wawancara tersebut di ketahui bahwa Dinas Pemberdayaan Perempuan dan Perlindungan anak Kota Mataram melaksanakan tugas dan fungsi sesuai dengan standar operasional prosedur dan peraturan perundang-undangan yang berlaku. Ada beberapa kegiatan yang telah dilakukan oleh Dinas Pemberdayaan Perempuan dan Perlindungan anak Kota Mataram antara lain melaksanakan kegiatan sosialisasi terkait pencegahan kekerasan pada perempuan dan anak di seluruh kelurahan yang ada di Kota Mataram, serta melaksanakan sosialisasi terkait pencegahan pernikahan di usia dini. Hal tersebut dilakukan agar tidak terjadi eksploitasi terhadap perempuan dan juga perempuan bisa meraih cita-cita dan berkarir sehingga tercipta sumber daya manusia perempuan yang kompetitif yang mampu bersaing.

Sekertaris Dinas Pemberdayaan Perempuan dan Perlindungan anak Kota Mataram juga menyampaikan bahwa:

"Peran dari Dinas Pemberdayaan Perempuan dan Perlindungan anak Kota Mataram tentunya sesuai dengan visi dan misi yaitu terwujudnya kesetaraan gender dan pemenuhan hak perempuan dan anak yang ada di Kota Mataram tentunya kami membuat beberapa program atau kebijakan seperti Stop Pernikahan usia sekolah dan stop kekerasan terhadap perempuan dan anak serta kami memberikan sosialisasi terhadap perempuan dan anak-anak agar melaporkan ke pihak yang berwajib apabila mendapatkan kekerasan dimanapun berada sesuai dengan peraturan yang berlaku, kami mengingatkan kepada perempuan untuk mengejar cita-cita karena kesempatan berkarir untuk perempuan dan laki-laki sama saja" Sumber: (hasil wawancara 20 januari 2018).

Sesuai dengan hasil wawancara di atas diketahui bahwa Dinas Pemberdayaan Perempuan dan Perlindungan anak Kota Mataram melaksanakan tugas dan fungsinya sesuai dengan visi dan misi yaitu terwujudnya kesetaraan gender dan pemenuhan hak perempuan dan anak yang ada di Kota Mataram. Dalam pelaksanaannya tentu Dinas Pemberdayaan Perempuan dan Perlindungan anak Kota Mataram bekerjasama dengan beberapa instansi terkait untuk melaksanakan sosialisasi kepada perempuan dan anak yang ada di Kota Mataram salah satunya bekerja sama dengan beberapa perguruan tinggi negeri dan swasta yang ada di Kota Mataram dan juga sekolahsekolah negeri dan swasta yang ada di Kota Mataram agar ikut mensosialisasikan beberapa program dari Dinas Pemberdayaan Perempuan dan Perlindungan anak Kota Mataram seperti stop pernikahan anak usia sekolah dan stop kekerasan terhadap perempuan dan anak yang ada di Kota Mataram. Seperti yang di 
ungkapkan oleh staf bidang pemberdayaan perempuan dan anak kota mataram bahwa:

"Kerjama dengan beberapa perguruan tinggi negeri dan swasta serta sekolah-sekolah yang ada di Kota Mataram dilakukan, tentunya untuk membantu meningkatkan kinerja dan pencapaian tujuan dari Dinas Pemberdayaan Perempuan dan Perlindungan anak Kota Mataram karena memang program terkait pemberdayaan perempuan dan perlindungan hak anak erat kaitannya dengan dunia pendidikan serta pentingnya sekolah, sehingga anak-anak usia sekolah tidak terburu-buru untuk menikah" sumber: (hasil wawancara 20 januari 2018).

Dari beberapa hasi wawancara diatas dapat disimpulkan bahwa dalam melaksanakan perannya secara efektif, untuk mencapai tujuan Dinas Pemberdayaan Perempuan dan Perlindungan Anak Kota Mataram yaitu terwujudnya kesetaraan gender dan pemenuhan hak perempuan dan anak yang ada di Kota Mataram. Untuk mencapai tujuan tersebut pengarahan sumber daya telah dilaksanakan oleh Dinas Pemberdayaan Perempuan dan Perlindungan Anak Kota Mataram dengan melaksanakan berbagai program dan sosialisasi terkait pemberdayaan perempuan, pemenuhan hak anak dan perempuan, pencegahan pernikahan anak usia sekolah dan stop kekerasan pada anak. Program tersebut bertujuan agar perempuan dan anak yang ada di Kota Mataram memperoleh haknya untuk hidup cerdas dan meraih cita-cita yang diinginkan.

Pencapaian tujuan yang efektif tentu menjadi pertanyaan yang penting, terkait sejauh mana ketercapaian tujuan yaitu terwujudnya kesetaraan gender dan pemenuhan hak perempuan dan anak di Kota Mataram. Untuk mengetahui hal tersebut, terkait pencapaian tujuan Dinas Pemberdayaan perempuan dan perlindungan anak Kota Mataram peneliti melakukan wawancara dengan Kepala Dinas Pemberdayaan perempuan dan perlindungan anak Kota Mataram yang menyatakan bahwa:

"Pencapaian tujuan sejauh ini tentunya sudah ada dengan menurunnya pernikahan usia sekolah serta kekerasan terhadap perempuan dan anak, persamaan hak perempuan dan laki-laki juga secara positif sudah terlaksana, tetapi untuk secara keseluruhan tujuan dari Dinas Pemberdayaan perempuan dan perlindungan anak Kota Mataram belum maksimal tercapai, karena disebabkan beberapa faktor, salah satunya masih rendahnya tingkat pendidikan perempuan di provinsi Nusa Tenggara Barat sehingga menyebabkan perempuan di Kota Mataram cenderung untuk cepat menikah, ini juga memberikan efek kepada kehidupan keluarga mereka setelah mempunyai anak tidak bisa memenuhi hak-hak anak dan mudah emosional sehingga terjadilah kekerasan dalam rumah tangga baik itu pada istri maupun anak itu sendiri" sumber: (hasil wawancara 19-01-2018).

Berdasarkan hasil wawancara dapat disimpulkan bahwa pencapaian tujuan dari Dinas Pemberdayaan perempuan dan perlindungan anak Kota Mataram belum tercapai secara efektif karena adanya beberapa permasalahan. Salah satunya tingkat pendidikan perempuan dan kesadaran masyarakat kota Mataram tentang hak perempuan dan anak masih rendah. Hal ini menyebakan pemerintah Kota Mataram dalam hal ini Dinas Pemberdayaan perempuan dan perlindungan anak Kota Mataram melaksanakan berbagai program berupa sosialisasi untuk menurunkan tingkat kekerasan pada perempuan dan anak yang ada di Kota Mataram. Sekertaris Dinas Pemberdayaan perempuan dan perlindungan anak Kota Mataram juga menyampaikan bahwa:

"Pencapaian tujuan sejauh ini belum tercapai secara efektif karena memang butuh proses, karena ini adalah masalah sosial dalam lingkungan masyarakat tentunya tetap akan terjadi tidak akan bisa langsung hilang sekaligus, jadi kami hanya melaksanakan tugas sesuai dengan tugas dan fungsi kami dan berusaha semaksimal mungkin untuk melawan oknum-oknum yang melakukan tindakan kekerasan terhadap perempuan dan anak serta pemenuhan hak perempuan dan anak yaitu mendapat pekerjaan yang layak, pendidikan yang layak dan pekerjaan yang di inginkan”. Sumber: (hasil wawancara 19-012018).

Dari hasil wawancara di atas dapat di simpulkan bahwa kekerasan terhadap perempuan dan anak yang terjadi di Kota Mataram tidak bisa langsung di hilangkan karena memang di pengaruhi oleh prilaku individu masing-masing orang dan lingkungan. Dinas Pemberdayaan perempuan dan perlindungan anak Kota Mataram berusaha memberikan edukasi bahayanya apabila terjadi kekerasan tehadap perempuan dan anak yaitu akan mempengaruhi mental dan fisik baik pada perempuan terlebih lagi pana anak yang akan mempengaruhi pertumbuhan dan perkembangan anak serta berdampak pada mental anak ketika tumbuh dewasa.

Faktor penyebab terjadinya kekerasan pada anak dan perempuan, secara keumuman disebabkan oleh suatu teori yang di kenal behubungan dengan stress dalam keluarga (family stress). Stres dalam keluarga tersebut bisa berasal dari anak, orang tua (suami atau Istri), atau situasi tertentu. Stres berasal dari anak misalnya anak dengan kondisi fisik, mental, dan perilaku yang terlihat berbeda dengan anak pada umumnya. Bayi dan usia balita, serta anak dengan 
penyakit kronis atau menahun juga merupakan salah satu penyebab stres. Stres yang berasal dari suami atau istri misalnya dengan gangguan jiwa (psikosis atau neurosa), orang tua sebagai korban kekerasan di masa lalu, orang tua terlampau perfek dengan harapan pada anak terlampau tinggi, orang tua yang terbiasa dengan sikap disiplin. Stres berasal dari situasi tertentu misalnya terkena suami/istri terkena PHK (pemutusan hubungan kerja) atau pengangguran, pindah lingkungan, dan keluarga sering bertengkar.

Namun tentunya teori tersebut hanya melingkupi kekerasan dalam rumah tangga. Penyebab utama lainnya adalah, kemiskinan, masalah hubungan social baik keluarga atau komunitas, penyimpangan prilaku social (masalah psikososial). Lemahnya kontrol social primer masyarakat dan hukum dan pengaruh nilai sosial kebudayaan di lingkungan social tertentu.

Diantara dampak kekerasan pada anak dan perempuan adalah stigma buruk yang melekat pada korban diantaranya; Pertama, Stigma Internal yaitu Kecenderungan korban menyalahkan diri, menutup diri, menghukum diri, menganggap dirinya aib, hilangnya kepercayaan diri, dan terutama adalah trauma sehingga seperti halnya perempuan tidak mau lagi berkeluarga setelah dirinya trauma menerima kekerasan dari suaminya.

Kedua, Stigma Eksternal yaitu, kecenderungan masyarakat menyalahkan korban, media informasi tanpa empati memberitakan kasus yang dialami korban secara terbuka dan tidak menghiraukan hak privasi korban. Selain stigma buruk yang melekat pada korban, kejahatan pada anak dan perempuan juga dapat menghancurkan tatanan nilai etika dan social seperti halnya dampak buruk dari human trafficking.

Staf Dinas Permberdayaan Perempuan dan Perlindungan Anak Kota Mataram menyatakan:

\begin{abstract}
“Agar kejadian kekerasan terhadap perempuan dan anak tidak kembali terjadi tentu harus diupayakan kerjasama dalam bentuk Pendekatan sosial melingkupi pendekatan partisipasi masyarakat dalam melaporkan dan waspada setiap tindakan kejahatan dan kekerasan terhadap perempuan dan anak, tidak perlu takut untuk melaporkan agar bisa di tangani oleh pemerintah, karena hal seperti ini apabila di biarkan bisa terulang kembali di kemudian hari” sumber: (hasil wawancara 22-01-2018).
\end{abstract}

Dari hasil wawancara diatas dapat disimpulkan bahwa untuk mencegah terjadinya kekerasan terhadap perempuan dan anak harus ada partisipasi masyarakat dan juga pihak terkait seperti institusi pendidikan dan pihak pemerintah harus bekerja sama untuk memberikan penyuluhan terhadap orang tua tentang bagaimana mengasuh anak dengan baik dan benar. Dan terakhir adalah pendekatan hukum, tentunya yang bertanggung jawab masalah ini adalah pemerintah untuk selalu mencari dan menanggapi secara sigap terhadap setiap laporan atau penemuan kasus kekerasan dan kejahatan dan menghukumnya dengan ketentuan hukum yang berlaku.

Kekerasan terhadap anak dalam Undangundang Nomor 35 Tahun 2014 adalah setiap perbuatan terhadap anak yang berakibat timbulnya kesengsaraan atau penderitaan secara fisik, psikis, seksual, dan/atau penelantaran, termasuk ancaman untuk melakukan perbuatan, pemaksaan, atau perampasan kemerdekaan secara melawan hukum.

Meski konsekuensi hukumannya cukup berat, dan kalangan pemerintah maupun masyarakat sipil pun telah bekerja keras mengatasinya dengan menghabiskan dana serta sumber daya lainnya yang kian tahun semakin meningkat, namun kasus-kasus kekerasan terhadap perempuan dan anak di negeri ini justru bertambah gawat dan mengkhawatirkan. Sepertinya para pelaku kekerasan itu tidak keder sedikit pun.

Dalam tahun 2015 saja, menurut Komisi Nasional Perempuan, terjadi sedikitnya 321.752 kasus kekerasan terhadap perempuan, atau rata-rata 881 kasus setiap hari. Dibanding tahun sebelumnya, angka ini meningkat 9\%. Sedangkan dalam catatan Komisi Perlindungan Anak Indonesia, pada tahun yang sama, terdapat 1.698 pengaduan kekerasan terhadap anak, 53\% di antaranya ialah kasus kekerasan seksual. Sisanya, yakni sebanyak 40,7\% adalah penelantaran, penganiayaan, eksploitasi seksual, dan berbagai bentuk kekerasan lainnya.

Lebih parahnya lagi, seperti yang dibuktikan melalui serangkaian penelitian serta pengalaman lapangan dari para pegiat anti kekerasan terhadap anak dan perempuan selama ini, ternyata hampir semua kasus kekerasan tersebut bukan hanya merupakan insiden-insiden yang hanya berhenti di situ, melainkan juga menjadi faktor-faktor yang memicu terjadinya berbagai jenis kekerasan lainnya terhadap perempuan, terutama perdagangan manusia (human trafficking) dan pemiskinan kaum perempuan atau feminisasi kemiskinan.

Kaum perempuan masih menjadi obyek tindak kekerasan di Kota Mataram provinsi Nusa Tenggara Barat. Tidak hanya dialami pasangan yang telah menikah, kekerasan juga terjadi terhadap perempuan yang masih bersatus pelajar. Hal tersebut diungkapkan Kepala Dinas Pemberdayaan 
Perempuan dan Perlindungan Anak (DPPPA) Mataram, Dra Hj Dewi Mardiana Ariany.

Kasus kekerasan terhadap perempuan dan anak di kota Mataram masih tinggi. Dinas Pemberdayaan Perempuan dan Perlindungan Anak (DP2PA) Kota Mataram mencatat, jumlah kekerasan terhadap perempuan dan anak sampai dengan Juli 2017 mencapai 68 kasus. Dengan rincian kekerasan terhadap perempuan sebanyak 63 persen dan anak sebesar 25 persen. Kekerasan ini didominasi oleh kekerasan fisik, seksual dan juga Kekerasan Dalam Rumah Tangga (KDRT). Ada berbagai penyebab, salah satunya faktor ekonomi suatu keluarga yang terkategori tidak stabil. Selain itu, kasus perselingkuhan juga menjadi penyebab timbulnya perkara serupa.

"Jumlahnya mencapai puluhan kasus, ini yang kita terima dari Unit PPA Polres Mataram. Bahkan ada pula yang dialami oleh siswa sekolah dasar," (hasil wawancara 20-012018)

Umumnya ketika ada indikasi kejadian kekerasan terhadap perempuan, mediasi selalu diutamakan DPPPA Mataram. Namun dinas tak dapat berbuat banyak ketika yang bersangkutan sudah membawa kasus ke ranah hukum. Jumlah kasus ini pun dinilai semakin meningkat dari tahun ke tahun.

Dinas Pemberdayaan perempuan dan Perlindungan Anak Kota Mataram membuka sentral pengaduan bagi perempuan di Mataram yang diduga mendapat tindakan kekerasan tersebut. Tidak hanya itu, bentuk advokasi juga disediakan karena yang diantisipasi adalah dampak secara psikis yang dialami perempuan.

"Ada pengaduan yang kami siapkan. Karena kita tidak ingin perempuan lantas mengalami trauma dan sejenisnya," (hasil wawancara 2201-2018)

Berdasarkan data Dinas Pemberdayaan Perempuan dan Perlindungan Anak (DPPPA) Mataram, pada tahun 2016 lalu jumlah kekerasan yang diidentifikasi mencapai 53 kasus. Rinciannya, pada triwulan pertama ditemui sebanyak 26 kasus. 10 kasus dialami perempuan di SLTA, 6 di SLTP, 7 di tingkat SD, 1 kasus dialami anak perempuan tidak sekolah, dan 2 kasus lain diderita perempuan yang bekerja di perusahaan. Sementara dalam triwulan kedua di tahun yang sama, jumlahnya meningkat menjadi 27 kasus. Dimana 9 kasus terjadi pada perempuan di tingkat SLTA, 7 kasus oleh perempuan di SLTP, 9 kasus lain terjadi pada perempuan tidak sekolah, dan 2 lagi dialami di tingkat perguruan tinggi.

Dari berbagai hasil wawancara dan data yang di peroleh peneliti dapat disimpulkan bahwa masih adanya tindakan kekerasan terhadap perempuan dan anak yang terjadi di kota Mataram disebabkan faktor ekonomi yang tidak stabil sehingga menyababkan emosi dan mengarah pada tindakan kekerasan terhadap perempuan dan anak, serta faktor perselingkuhan juga menjadi salah satunya, persoalan ini harus harus diatasi dengan sinergi dengan semua pihak. Di satu sisi ia berharap peran aktif dari para korban kekerasan ini agar tidak takut melapor kepada aparat dan pemerintah daerah sehingga segera diambil tindakan lebih lanjut. Pihaknya juga memberikan psikolog pendamping kepada para korban, baik itu untuk perempuan maupun anak. Bagi para korban kekerasan perempuan, diberikan pembinaan ekonomi untuk meningkatkan kesejahteraan serta mengatasi trauma yang mungkin dialaminya.

\section{B. Faktor Pendorong Dan Penghambat Peran Dinas Pemberdayaan Perempuan Dan Perlindungan Anak Kota Mataram}

Peran Dinas Pemberdayaan Perempuan dan Perlindungan Anak Kota Mataram sesuai tugas pokok dan fungsinya untuk memenuhi hak perempuan dan anak agar terhindar dari kekerasan dalam rumah tangga (KDRT) atau kekerasan di lingkungan sosial lainnya, tentu menjadi tantangan yang harus di hadapi oleh Dinas Pemberdayaan Perempuan dan Perlindungan Anak Kota Mataram. Seperti yang diungkapkan oleh kepala Dinas Pemberdayaan Perempuan dan Perlindungan Anak Kota Mataram bahwa:

"Dalam melaksanakan tugas dan fungsi kami, kami mempunyai strategi dan sasaran yang jelas hal tersebut memudahkan kami dalam mencapai tujuan, adapun strategi yang kami lakukan adalah melaksanakan sosialisasi di seluruh kelurahan yang ada di Kota Mataram. Kami juga bekerjasama dengan perguruan tinggi dan sekolah untuk ikut memberikan sosialisasi pencegahan terjadinya tindakan kerkerasan pada perempuan dan anak di Kota Mataram" sumber: (hasil wawacara 23-012018).

Menurut hasil pengaduan yang diterima KOMNAS Perlindungan Anak (2006), pemicu kekerasan terhadap anak yang terjadi diantaranya adalah :

1) Kekerasan dalam rumah tangga, yaitu dalam keluarga terjadi kekerasan yang melibatkan baik pihak ayah, ibu dan saudara yang lainnya. Kondisi menyebabkan tidak terelakkannya kekerasan terjadi juga pada anak. Anak seringkali menjadi sasaran kemarahan orang tua,

2) Disfungsi keluarga, yaitu peran orang tua tidak berjalan sebagaimana seharusnya. Adanya disfungsi peran ayah sebagai pemimpin keluarga 
dan peran ibu sebagai sosok yang membimbing dan menyayangi,

3) Faktor ekonomi, yaitu kekerasan timbul karena tekanan ekonomi. Tertekannya kondisi keluarga yang disebabkan himpitan ekonomi adalah faktor yang banyak terjadi,

4) Pandangan keliru tentang posisi anak dalam keluarga. Orang tua menganggap bahwa anak adalah seseorang yang tidak tahu apa-apa. Dengan demikian pola asuh apapun berhak dilakukan oleh orang tua.

Ada 2 faktor yang melatarbelakangi munculnya kekerasan anak oleh orang tuanya. Faktor tersebut masing-masing berasal baik dari orang tua maupun anak sendiri. 2 faktor tersebut antara lain;

a) Orang tua yang pernah jadi korban penganiayaan anak dan terpapar oleh kekerasan dalam rumah, orang tua yang kondisi kehidupannya penuh sters, seperti rumah yang sesak, kemiskinan, orang tua yang menyalahgunakan NAPZA, orang tua yang mengalami gangguan jiwa seperti depresi atau psikotik atau gangguan keperibadian.

b) Anak yang premature, anak yang retardasi mental, anak yang cacat fisik, anak yang suka menangis hebat atau banyak tuntutan. Berdasarkan uraian tersebut baik orang tua maupun anak sama-sama berpengaruh pada timbulnya kekerasan pada anak. Sumber: (Diolah dari data sekunder 24-01-2018).

Sekertaris Dinas Pemberdayaan Perempuan

dan Perlindungan Anak Kota Mataram juga menyampaikan bahwa:

"Penghambat peran Dinas Pemberdayaan Perempuan dan Perlindungan Anak Kota Mataram adalah masih kurangnya kesadaran masyarakat untuk mengikuti kegiatan sosialisasi stop kekerasan terhadap perempuan dan anak menjadi tantangan tersendiri, karena menyadarkan sebuah keluarga itu tidak mudah di sebabkan oleh pola pikir dan wawasan yang sempit menjadikan tujuan Dinas Pemberdayaan Perempuan dan Perlindungan Anak Kota Mataram tidak mudah untuk di capai”sumber: (hasil wawancara 23-01-2018).

Kekerasan pada anak-anak bukan hanya merupakan problem personal. Jika hanya menimpa segelintir anak-anak saja, dapat dilacak pada sebabsebab psikologis dari individu yang terlibat. Pemecahannya juga dapat dilakukan secara individual. Memberikan terapi psikologis pada baik pelaku maupun korban mungkin akan cepat selesai. Tetapi jika perilaku memperkerjakan anak kecil dalam waktu yang panjang, menelantarkan mereka, atau menyakiti dan menyiksa anak itu terdapat secara meluas di tengah-tengah masyarakat maka berhadapan dengan masalah sosial. Penyebabnya tidak boleh lagi dilacak pada sebab-sebab individual.
Melacaknya pada nilai, pola interaksi sosial, struktur sosial ekonomi, dan atau pranata sosial. Pemecahannya memerlukan tindakan kolektif dari seluruh anggota masyarakat. Rakhmat (2003). Rakhmat (2003) membagi faktor sosial antara lain:

1) Norma sosial, yaitu tidak ada kontrol sosial pada tindakan kekerasan pada anak-anak, maksudnya ketika muncul kekerasan pada anak tidak ada orang di lingkungannya yang memperhatikan dan mempersoalkannya;

2) Nilai-nilai sosial, yaitu hubungan anak dengan orang dewasa berlaku seperti hirarkhi sosial di masyarakat. Atasan tidak boleh dibantah. Aparat pemerintahan harus selalu dipatuhi. Guru harus digugu dan ditiru. Orangtua tentu saja wajib ditaati dengan sendirinya. Dalam hirarkhi sosial seperti itu anak-anak berada dalam anak tangga terbawah. Mereka tidak punya hak apa pun, sedangkan orang dewasa dapat berlaku apa pun kepada anak-anak;

3) Ketimpangan sosial. Banyak ditemukan bahwa para pelaku dan juga korban child abuse kebanyakan berasal dari kelompok sosial ekonomi yang rendah. Kemiskinan, yeng tentu saja masalah sosial lainnya yang diakibatkan karena struktur ekonomi dan politik yang menindas, telah melahirkan semacam subkultur kekerasan. Karena tekanan ekonomi, orangtua mengalami stress yang berkepanjangan. Ia menjadi sangat sensisitif. Ia mudah marah. Kelelahan fisik tidak memberinya kesempatan untuk bercanda dengan anak-anak. Terjadilah kekerasan emosional.

Kekerasan tersebut diperlukan tindakan kolektif untuk mengatasinya, memerlukan proses pendidikan yang terus menerus untuk mensosialisasikan nilai-nilai demokratis dan penghargaan pada hak-hak anak-anak, berusaha menegakkan undang-undang yang melindungi anakanak dari perlakuan sewenang-wenang orang-orang dewasa dan membangun lembaga-lembaga advokasi anak-anak.

Staf Dinas Pemberdayaan Perempuan dan Perlindungan Anak Kota Mataram juga menyampaikan bahwa:

"Harus ada sosialisasi berkelanjutan untuk mendorong dan mencegah terjadinya kekerasan terhadap perempuan dan anak di Kota Mataram. Dengan adanya sosialisasi berkelanjutan dari tingkat RT,RW dan kelurahan di harapkan kepala keluarga bisa memahami pentingnya memecahkan permasalahan kelurga dengan tidak bersifat emosional kepada istri dan anak, laki-laki dewasa pada perempuan dewasa serta pada anak-anak karena akan berdampak jangka panjang dan ikut merusak generasi selanjutnya" sumber: (hasil wawancara 24-012018). 
Dari hasil wawancara dan data yang diperoleh peneliti, dapat disimpulkan bahwa faktor pendorong keberhasilan peran Dinas Pemberdayaan Perempuan dan Perlindungan Anak di Kota Mataram yaitu adanya strategi yang jelas oleh Dinas Pemberdayaan Perempuan dan Perlindungan Anak kota Mataram dalam hal ini berkaitan dengan pelaksanaan kegiatan sosialisasi stop kekerasan terhadap perempuan dan anak di seluruh kelurahan yang ada di Kota Mataram. Kami juga bekerjasama dengan perguruan tinggi dan sekolah untuk ikut memberikan sosialisasi pencegahan terjadinya tindakan kerkerasan pada perempuan dan anak di Kota Mataram. Selain itu Dinas Pemberdayaan Perempuan dan Perlindungan Anak Kota Mataram menghimbau kepada Kepala Kelurahan, Ketua RT, RW untuk memberikan pemahaman pada warganya untuk tidak melakukan tindakan kekerasan terhadap perempuan dan anak yang ada di Kota Mataram sesuai dengan UndangUndang yang berlaku.

Ada beberapa faktor yang harus di hindari agar tidak terjadinya tindakan kekerasan pada perempuan dalam rumah tangga yang harus di hindari agar peran Dinas Pemberdayaan Perempuan dan Perlindungan Anak Kota Mataram bisa berjalan efektif yaitu:

\section{Sikap povokatif korban}

Sikap korban yang dengan sengaja maupun tidak membuat pelaku marah adalah salah satu sebab terjadinya kekerasan. Sikap tersebut seperti: pecemburu, suka ngomil, pengabaian pengurusan rumah tangga, penuntut, histerik, masokistik, suka menjawab balik, suka betengkar, melawan dengan kata-kata kasar.

\section{Kurang menghargai suami.}

Salah satu sebab mengapa suami ganas terhadap isteri ialah isteri kurang menghargai keluarga suami. Banyak kasus kekerasan disebabkan oleh isteri yang tidak menghargai suami bahkan mertua sendiri. Hal ini disebabkan korban berasal dari keluarga terpandang, kaya, pekerjaan, sukses, tidak melayani suami dengan sempurna.

\section{Ketergantungan}

Ketergantungan isteri membuat suami merasa berkuasa penuh, sehingga dapat melakukan apa saja termasuk kekerasan. Ketergantungan dapat disebabkan oleh rendahnya pendidikan, tidak memiliki keterampilan. untuk kuasa mendapatkan keadilan, tidak bekerja atau tidak memiliki penghasilan, tidak percaya diri bila berpisah, tidak kuasa memulai hidup baru, memelihara dan menanggung anak, dan takut terhadap kritikan masyarakat.

1. Tidak mau melapor
Banyak korban kekerasan tidak memahami bahwa apa yang mereka alami adalah kekerasan dalam rumah tangga, sehingga mereka memandang bahwa kekerasan yang mereka alami adalah masalah biasa, di samping korban merasa bersalah dan layak mendapatkan kekerasan. Padahal kesadaran korban untuk untuk melapor sangat diperlukan. Rika Saraswati (2006)mengatakan, faktor utama penyelesaian kasus kekerasan rumah tangga berasal dari diri korban itu sendiri. Korban harus sadar bahwa kekerasan dalam rumah tangga yang berlaku pada dirinya merupakan penghinaan terhadap harkat dan martabat perempuan, bertentangan dengan undang-undang serta melanggar hak asas manusia.

Women's Aid Organization (WAO) mengatakan sebab korban tidak mau melapor seperti: menganggap perkara itu perkara kecil, malu, dianggap membuka aib keluarga, takut dipersalahkan, takut suami lebih ganas lagi, takut dicerai, tidak yakin aduannya direspon dengan baik, sukar membuktikan kekerasan yang dialami, takut suami dipenjara, ketidaktahuan korban mengenai prosedur penyampaian laporan, kurangnya kepedulian masyarakat, khawatir korban mengenai berlakunya ketidakharmonisan antara korban dengan pelaku, dengan keluarga pelaku, atau antara keluarga korban dengan keluarga pelaku, dan tidak adanya keyakinan dalam diri korban bahwa kasus kekerasan tersebut akan ditangani secara adil. Alasan lainnya seperti: merasa jiwanya terancam, takut tidak diberi nafkah, takut dianggap membongkar aib keluarga. Ditambah pula kebanyakan masyarakat yang menganggap kekerasan rumah tangga adalah sebagai masalah keluarga yang tabu diungkap kerap menyarankan 'berdamai saja' sebagai solusi untuk kasus seperti ini.

\section{Berpegang kepada tradisi atau adat}

Kuatnya tradisi atau adat yang diikuti dapat menjadi faktor pendorong terjadinya kekerasan seperti: korban percaya bahwa perkahwinan adalah suci dan oleh itu coba bertahan dalam menghadapi apa pun kekerasan yang dilakukan oleh suami, korban menganggap kekerasan adalah suatu takdir, anggapan bahwa wanita harus patuh kepada suami, sikap masyarakat yang tidak peduli terhadap masalah tetangga, serta menjadikan kedudukan wanita sebagai sabordinasi di ranah domestik.

\section{Faktor eksternal korban}

Selain daripada faktor internal korban, faktor eksteral korban juga boleh menjadi sebab berlakunya kekerasan terhadap wanita dalam rumah tangga, seperti:

1. Sifat pribadi pelaku

Sifat pribadi atau psikopatologi pelaku merupakan hal yang dapat menimbulkan terjadinya kekerasan dalam rumah tangga, seperti: jiwa terganggu, perasaan tertekan, kurang percaya diri, 
tidak berfikiran matang, muram, skizofrenia (penyakit mental), kemahiran berkomunikasi yang rendah, pecandu narkoba, peminta, selalu betul, pecemburu, dan sensitif.

\section{Tekanan hidup}

Tekanan hidup dapat menjadi penyebab kekerasan dalam rumah tangga seperti: akibat konflik, beratnya penderitaan perkawinan, tidak mempunyai pekerjaaan, merasa lebih lemah daripada isteri, dan pernah melihat perbuatan kekerasan atau pernah dipukul pada masa kecil.

3. Ketimpangan gender dan sosial

Ketimpangan atau ketidakadilan gender tersebut terlihat dengan adanya perbedaan peran dan hak wanita dan lelaki di masyarakat yang menempatkan wanita dalam status lebih rendah dari lelaki. "Hak istimewa yang dimiliki lelaki ini seolaholah menjadikan wanita sebagai "barang" milik lelaki yang berhak untuk diperlakukan sesuka hati, termasuk dengan kekerasan, termasuk pula dalam perkara ini bilamana perempuan dilihat sebagai obyek untuk dimiliki dan dipedagangkan oleh lelaki, dan bukan sebagai individu dengan hak atas tubuh dan kehidupannya.

Lelaki dianggap lebih utama daripada wanita, sehinggga status wanita dianggap lebih rendah dan kurang berharga berbanding lelaki. wanita merupakan soalan yang lumrah terjadi sebagai konsekuensi daripada struktur masyarakat yang lebih mementingkan atau didominasikan oleh lelaki. Sita Aripurnami (1999) mengatakan bahwa ketimpangan seperti ini akan menciptakan sebuah kondisi sosial dimana pihak berkuasa boleh menggunakan kekuasaannya secara berlebihan kepada pihak yang lemah. Wanita dianggap tidak berkuasa dan amat bergantung kepada suaminya dalam segala urusan, kurang pemahaman agama secara betul, Gellas RJ (1977) mengatakan bahwa status subordinasi wanita di kebanyakan masyarakat di dunia ini telah menyebabkan wanita sebagai korban kekerasan, terutamanya dalam konteks kekerasan rumah tangga. Achie Sudiarti Luhulima dan Kunthi Tridewiyanti (1999) sikap tradisonal yang menganggap sebagai subordinasi lelaki dan pembekuan peran-peran stereotaip. dan sikap tradisional yang menganggap bahwa apa yang terjadi dalam rumah tangga merupakan hal yang sebaiknya diselesaikan dalam rumah tangga pula. corak budaya, kefahaman atau adat yang melampaui batas yang berkaitan dengan bangsa, seks, bahasa atau agama yang menggambarkan kedudukan rendah wanita di dalam keluarga, masyarakat dan di tempat kerja, kaum lelaki sering mendahului wanita dalam pelbagai bidang; dan sistem dalam sesuatu keluarga yang memberikan kuasa kepada kaum lelaki dalam segala hal, menganggap wanita makhluk yang rendah dan hina, di mana fungsinya hanyalah untuk mengurus rumah tangga dan memperbaiki keturunan.

4. Masalah keuangan

Masalah keuangan sering menjadi pemicu kekerasan dalam rumah tangga, selain itu terlalu banyak menuntut ke kepada suami sedangkan suami tidak dapat memenuhinya.Dikatakan bahwa ramai isteri yang bertahan atau mahu menerima penganiayaan suami adalah mereka yang tidak mandiri di bidang ekonomi atau keuangan. Para isteri yang mandiri lebih beruntung nasibnya berbanding dengan mereka yang secara ekonomi bergantung kepada suami. Ni Nyoman (2008) juga mengatakan, ketidak mandirian isteri atau ketergantungan isteri isteri terhadap suami di bidang ekonomi juga boleh menjadi sebab kekerasan, walaupun tidak sepenuhnya demikian.

5. Budaya paternalistik dan pemahaman budaya yang keliru.

Budaya paternalistik yang menganggap kaum lelaki sebagai pemegang kekuasaan dipersepsikan sebagai struktur yang menempatkan wanita pada posisi subordinat dibandingkan dengan lelaki, yang dapat menimbulkan berbagai bentuk deskriminasi terhadap wanita. Banyak kasus kekerasan terhadap wanita lebih bersumber daripada ketimpangan kekuasaan antara wanita dengan lelaki. Lelaki dianggap pemberani, tegas dalam bertindak, sebaliknya wanita harus bersikap pasrah, mengalah, tugas pengasuhan, pelayanan, dan pendampingan suami dan anak-anak makin menempatkan wanita pada posisi yang lemah dan tidak penting bagi lelaki yang juga dapat menjadi sebab kekerasan terhadap wanita.

Kuatnya budaya paternalistik menimbulkan pemahaman budaya yang keliru, di mana seorang isteri harus tunduk kepada suami. Hasil kajian yang dilaksanakan di Papua menunjukkan anggapan yang dominan bahwa tindak kekerasan terhadap wanita adalah persoalan keluarga dan adat-istiadat setempat yang proses penyelesaiannya cukup di tingkat keluarga dan adat. Selain itu pula, dalam kondisi umum dimana kekerasan boleh terjadi adalah sebagai reaksi kecemburuan sosial dan pemilikan, sebagai cara menegakkan kemahuan layanan domestik, sebagai cara membina atau mengekalkan kekuasaan lelaki, dan sebagai penunjuk kekuasaan lelaki serta keistimewaannya.

Stigma sosial dalam masyarakat yang menganggap wanita sebagai orang yang tidak normal dan dipandang pembawa aib sehingga diperlakukan rendah dan berbeza dengan lelaki juga merupakan sebab timbulnya kekerasan terhadap wanita. Selain itu dalam pengembangan teori stigma sosial, wanita adalah salah satu kelompok yang rentan mendapatkan stigma. 


\section{Kehadiran pihak lain}

Kehadiran pihak lain dapat menimbulkan cemburu. Bila cemburu berlebihan serta prasangka yang buruk dapat menjadi sebab kekerasan terhadap ister. Hal ini banyak terjadi pada wanita yang bekerja, karena mereka terpaksa berurusan dengan lelaki lain. Isteri-isteri yang melakukan hubungan luar nikah dengan lelaki lain. Isteri menunjukan minat kepada lelaki lain kerana ini membawa erti ancaman penarikan balik cinta secara fisik dan mental oleh seseorang isteri ke atas suaminya dan ini tidak dapat diterima oleh suami, suami akan berasa dirinya tidak mempunyai kawalan ke atas haknya dan berasa tidak selamat kerana kemungkinan pembelotan isteri. Oleh itu, suami akan memastikan bahwa isterinya akan meninggalkannya melalui kawalan ketat dan penganiayaan formal serta mental. Perselingkuhan. Ibnu Syakrani (2006) mengatakan bahwa selingkuh juga erat kaitannya dengan kekerasan dalam rumah tangga. Sebab ketika suami kedapatan tidak setia, kerana rongrongan "cinta buta" pada orang ketiga, tak segan bertindak apatis dan bahkan melakukan pemukulan kepada isterinya.

\section{KESIMPULAN DAN SARAN}

\section{Kesimpulan}

a) Kekerasan terhadap perempuan dan anak yang terjadi di Kota Mataram tidak bisa langsung di hilangkan karena memang di pengaruhi oleh prilaku individu masing-masing orang dan lingkungan. Kasus kekerasan terhadap perempuan dan anak di kota Mataram masih tinggi. Dinas Pemberdayaan Perempuan dan Perlindungan Anak (DP2PA) Kota Mataram mencatat, jumlah kekerasan terhadap perempuan dan anak sampai dengan Juli 2017 mencapai 68 kasus. Dengan rincian kekerasan terhadap perempuan sebanyak 63 persen dan anak sebesar 25 persen. Kekerasan ini didominasi oleh kekerasan fisik, seksual dan juga Kekerasan Dalam Rumah Tangga (KDRT). Ada berbagai penyebab, salah satunya faktor ekonomi suatu keluarga yang terkategori tidak stabil. Masih adanya beberapa permasalahan yang terjadi menyebabkan Peran Dinas Pemberdayaan Perempuan dan Perlindungan Anak dalam mencegah tindak kekerasan pada perempuan dan anak di Kota Mataram belum terlaksana secara efektif.

b) Faktor pendorong keberhasilan peran Dinas Pemberdayaan Perempuan dan Perlindungan Anak di Kota Mataram yaitu adanya strategi yang jelas oleh Dinas Pemberdayaan Perempuan dan Perlindungan Anak kota Mataram dalam hal ini berkaitan dengan pelaksanaan kegiatan sosialisasi stop kekerasan terhadap perempuan dan anak di seluruh kelurahan yang ada di Kota Mataram. Kami juga bekerjasama dengan perguruan tinggi dan sekolah untuk ikut memberikan sosialisasi pencegahan terjadinya tindakan kerkerasan pada perempuan dan anak di Kota Mataram. Selain itu Dinas Pemberdayaan Perempuan dan Perlindungan Anak Kota Mataram menghimbau kepada Kepala Kelurahan, Ketua RT, RW untuk memberikan pemahaman pada warganya untuk tidak melakukan tindakan kekerasan terhadap perempuan dan anak yang ada di Kota Mataram sesuai dengan Undang-Undang yang berlaku. Sedangkan faktor penghambatnya yaitu Penghambat peran Dinas Pemberdayaan Perempuan dan Perlindungan Anak Kota Mataram adalah masih kurangnya kesadaran masyarakat untuk mengikuti kegiatan sosialisasi stop kekerasan terhadap perempuan dan anak. Kekerasan tersebut diperlukan tindakan kolektif untuk mengatasinya, memerlukan proses pendidikan yang terus menerus untuk mensosialisasikan nilai-nilai demokratis dan penghargaan pada hak-hak anak-anak, berusaha menegakkan undang-undang yang melindungi anak-anak dari perlakuan sewenang-wenang orang-orang dewasa dan membangun lembagalembaga advokasi anak-anak.

\section{Saran}

a) Persoalan kekerasan terhadap perempuan dan anak harus diatasi dengan sinergi dengan semua pihak. Di satu sisi ia berharap peran aktif dari para korban kekerasan ini agar tidak takut melapor kepada aparat dan pemerintah daerah sehingga segera diambil tindakan lebih lanjut. Pihaknya juga memberikan psikolog pendamping kepada para korban, baik itu untuk perempuan maupun anak. Bagi para korban kekerasan perempuan, diberikan pembinaan ekonomi untuk meningkatkan kesejahteraan serta mengatasi trauma yang mungkin dialaminya.

b) Harus ada partisipasi masyarakat dan juga pihak terkait seperti institusi pendidikan dan pihak pemerintah harus bekerja sama untuk memberikan penyuluhan terhadap orang tua tentang bagaimana mengasuh anak dengan baik dan benar. Dan terakhir adalah pendekatan hukum, tentunya yang bertanggung jawab masalah ini adalah pemerintah untuk selalu mencari dan menanggapi secara sigap terhadap setiap laporan atau penemuan kasus kekerasan dan kejahatan dan menghukumnya dengan ketentuan hukum yang berlaku.

\section{Daftar Pustaka}

Alya, Qonita. 2009. Kamus Bahasa Indonesia. Jakarta: PT Indah Jaya Adipratama

Atmasasmita, Romli.1997.Peradilan Anak di Indonesia.Bandung: Mandar Maju

Azra, Azyumardi. 2003. Pendidikan Kewargaan (Civic Education): Demokrasi,

Hak Asasi Manusia dan Masyarakat Madani. Jakarta: Prenada Media.

Gaffar, Afan. 2004. Politik Indonesia: Transisi Menuju Demokrasi. Yogyakarta:

Penerbit Pustaka Pelajar

Hafsah, Mohammad Jafar. 2000. Kemitraan Usaha, Konsepsi Dan Strategi,

Jakarta:Pustaka Sinar Harapan

Herdiansyah, Haris. 2012. Metodologi Penelitian Kualitatif. Jakarta: Salemba

Humanika

Hikam, Muhammad AS. 1999. Demokrasi dan Civil Society. Jakarta: Pustaka

LP3ES Indonesia, Anggota IKAPI 
Hurairah, Abu. 2008. Pengorganisasian dan Pengembangan Masyarakat Model

dan Strategi Pembangunan yang Berbasis Kerakyatan. Bandung:

Humaniora

Kuncoro, Jede. 2007. From Competiting to Collaboration. Jakarta: Gramedia

Pustaka

Linton, Ian. 1997. Kemitraan Meraih Keuntungan Bersama. Jakarta: Hailarang

Moleong, Lexy J. 2011. Metode Penelitian Kualitatif (Edisi Revisi). Bandung:

Remaja Rosdakarya

Notoatmodjo, Soekidjo. 2010. Promosi Kesehatan (Teori dan Aplikasi). Jakarta:

PT Rineka Cipta

Rukmana. Nana. 2006. Strategic Partnering For Educational Management.

Bandung: Alfabeta

http://sip-ppid.mataramkota.go.id/skpd-270-dinaspemberdayaan-perempuan-dan-perlindungan-anak

http://sip-ppid.mataramkota.go.id/file/profil-dinaspemberdayaan-perempuan-dan-perlindungananak.pdf

http://sip-ppid.mataramkota.go.id/file/visi-misipemberdayaan-perempuan-dan-perlindungananak.pdf

https://ideguru.wordpress.com/2010/04/22/faktor-faktoryang-melatar-belakangi-kekerasan-pada-anak/

http://www.kpai.go.id/files/2013/o9/uu-nomor-35-tahun2014-tentang-perubahan-uu-pa.pdf

https://kicknews.today/2017/07/27/kota-mataram-hadapipuluhan-kasus-kekerasan-terhadap-perempuan/

https://hanafiariefjurnal.wordpress.com/2013/12/08/fakto r-penyebab-terjadinya-kekerasan-terhadap-wanitadalam-rumah-tangga/

https://globalfmlombok.com/read/2017/10/20/kasuskekerasan-perempuan-dan-anak-di-matarammasih-tinggi.html

https://radarlombok.co.id/kekerasan-perempuan-dananak-538-kasus.html

https://www.eramuslim.com/suara-kita/pemudamahasiswa/kekerasan-pada-anak-dan-perempuandampak-dan-solusinya.htm\#.WpmgeaiWbIU 